\title{
SSinteza
}

Impact of Internet on Business Activities in Serbia and Worldwide

Uticaj Interneta na poslovanje u Srbiji i svetu

DOI: 10.15308/SINTEZA-2014-385-388

\section{SPOSOBNOST UČENIKA SREDNJIH ŠKOLA ZA KORIŠĆENJE INTERNETA U OBRAZOVNE SVRHE}

\author{
Ivan Nikčević1, Elena Marković ${ }^{2}$ \\ ${ }^{1}$ Univerzitet Singidunum, Beograd \\ ${ }^{2}$ Dom učenika srednjih škola Zaječar
}

\begin{abstract}
:
Razvoj informacionih tehnologija dovodi do mogućnosti uvođenja savremenijih i produktivnijih metoda rada i usavršavanja u svim sferama društvenog života, ali i u obrazovanju i vaspitanju. Cilj ovog istraživanja je bio da se ispita koja su intersovanja učenika u oblasti informacionih tehnologija i koliko su učenici srednjih škola spremni da svoje znanje iz informatike primene na druge nastavne predmete i unaprede svoja akademska postignuća. Rezultati istraživanja pokazali su da učenici koriste sadržaje sa interneta najviše u zabavne svrhe, a koriste ih i za učenje i potrebe škole ali im to ne utiče na akademska postignuća iz ostalih predmeta. To upućuje na potrebu organizovanije upotrebe informacionih tehnologija i optimalnijeg korišćenja u edukativne svrhe.
\end{abstract}

\section{UVOD}

Kompjuter potiče od engleske reči i u početku je označavala klasične mehaničke računare, dok se danas koristi za elektronske računare koji rade na osnovu određenih programa koji mogu da izvode različite operacije upravljane konkretnim programima [5]. Uz pomoć kompjutera moguće je obrađivati razne numeričke podatke, vršiti preradu podataka i informacija i prikaz obrađenog. Internet predstavlja mrežu kompjutera različitih platformi čije se funkcionisanje zasniva na sistemu adresiranja i ustanovljavanja prenosnog protokola za paket posredničkih uslu$\mathrm{ga}[3]$.

Svaki računar priključen na internet mora da raspolaže jedinstvenom IP-adresom. Internet predstavlja vrstu komunikacijskog medija koji omogućava bržu komunikaciju i razmenu ideja, nov način mišljenja i razmišljanja, drugačije mogućnosti ličnog izražavanja i učestvovanje u različitim diskusijama sa drugim pojedincima i grupama. Omogućuje veću fleksibilnost u pogledu vremena i prostorne lokacije prilikom slanja i primanja informacija, veći izvor informacija o raznim sadržajima, pa tako na internetu se mogu pronaći razna dokumenta, zakoni, objave i na taj način se mogu uvek i redovno pratiti novine iz raznih sfera društvenih zbivanja [4].
Putem interneta je moguć bolji pristup zabavnim, obrazovnim, naučnim i brojnim drugim sadržajima. Internet je medij koji omogućava digitalno simuliranje različitih masovnih medija, kao što su štampa, televizija, radio, ali i individualizovanih komunikacijskih medija, kao što su pismo, telefaks, telefon i drugi. Sve veći broj različitih ljudskih aktivnosti povezuje se sa Internetom (obrazovanje, nauka, kultura, trgovina, zabava), pa se podrazumeva kako je internet sve prisutniji i uticajniji činilac u radu i životu mnogih pojedinaca, ustanova i zajednica. Informaciona tehnologija i internet predstavljaju stvaranje različitih baza podataka, koje bi indirektno trebalo da pomognu povećanju efikasnosti funkcionisanja društva gde obrazovanje predstavlja bazičnu osnovu. Uz pomoć interneta zanimljivi materijali koji su relevantni za nastavu mogu biti stečeni [7].

\section{INTERNET U OBRAZOVANJU}

Reforma obrazovanja koja je u toku podrazumeva stvaranje uslova i sistema koji će uključivati mnoge stručnjake iz te oblasti i nastavnike koji će učestvovati u procesu izrade obrazovnih planova i programa, didaktičkih materijala, pružiti brojne mogućnosti i stvoriti sistem koji će postojati, savremenije metode u podučavanju i učiniti 
obrazovanje dostupnijim. Čine se napori da se formalan proces inovira i uskladi sa dostignućima informaciono komunikacione tehnologije. Organizovanjem seminara i obuke za zaposlene u obrazovanju ide se ka efikasnijim putevima učenja, koji bi bili u skladu sa posebnostima, preokupacijama i interesovanjima novih generacija učenika svih uzrasta. Obzirom da tradicionalni metodički pristupi u obrazovanju ne pružaju dovoljno mogućnosti za optimalno izvođenje nastave, teži se boljim efektima i javlja se potreba za inovacijom obrazovnih tehnologija u smislu svrsishodnije upotrebe računara i internet kao modernijih nastavnih sredstava.

Efikasnije integrisanje informaciono - komunikacionih i obrazovnih tehnologija definisano je Smernicama za unapređivanje uloge informaciono komunikacionih tehnologija, IKT, u obrazovanju od strane Nacionalnog prosvetnog saveta Republike Srbije 2013-te godine. Smernice predstavljaju dokument u čijoj je izradi učestvovao veći broj eksperata i odnosi se na prilagođavanje standarda (obrazovnih, kompetencija nastavnika i direktora, kvaliteta rada škola, udžbenika), planova i programa; pomoć i podršku nastavnicima u ovladavanju novim sredstvima, metodama i sadržajima; izradu i raspoloživost digitalnih obrazovnih sadržaja, koji moraju biti pristupačni kako bi omogućili i integrisanje osetljivih grupa kao što su deca i učenici sa invaliditetom; opremljenost škola, razvoj infrastrukture i obezbeđivanje opreme koju učenici koriste van škole; obrazovne informacione sisteme [6]. Dokument se sastoji od nekoliko celina koje obuhvataju: osnovne pojmove i principe uspešne integracije IKT u obrazovanju, sistemsko okruženje za uspešnu integraciju IKT, ulogu u IKT u ciljevima i ishodima obrazovanja, IKT u funkciji nastave i IKT u pojedinim oblastima obrazovne politike. U dokumentu su definisane preporuke na nivou strategije razvoja, preporuke na nivou obrazovnih institucija, kao i preporuke na nivou nastavne prakse. U Zakonu o osnovama sistema obrazovanja i vaspitanja, dati su krovni principi na osnovu kojih treba planirati i primenjivati IKT u okviru sistema obrazovanja.

\section{INTERNET I MLADI}

Eksplozivni način razvoja informacione tehnologije menja način življenja i komuniciranja čime dolazi do bržih i značajnijih promena u razmišljanju. Usled sadašnje tehnološke revolucije, naši mozgovi upravo u ovom trenutku evoluiraju brzinom kao nikad do sad [2] . Količina vremena provedena za računarom stimuliše mnoge promene u razmišljanju i osećanjima i način na koji "mozgovi” funkcionišu. Doba adolescencije predstavlja specifičnu i kritičnu fazu razvoja gde način razmišljanja napreduje od konkretnog ka apstraktnom. Po Pijažeu, period do dvanaeste godine, je faza konkretnih operacija kada se razvija logičko razmišljanje o konkretnim događajima, a period formalnih operacija, kada dolazi do apstraktnog zaključivanja traje sve do 19-te godine. Taj period predstavlja doba kada adolescenti razvijaju sposobnost razumevanja emocionalnih iskustva drugih i vežbanje empatijskih veština [1]. Provođenje više vremena za računarom, gde istovremeno učestvuju u više aktivnosti, dovodi do otežanog razvoja navedenih sposobnosti. Trenutno zadovoljenje želja adolescenata je na prvom mestu i oni ne žele njihovo odlaganje. Sa normalnim sazrevanjem, jača se sposobnost rasuđivanja i odlaganje zadovoljenja potreba i želja, dolazi do uvažavanja osećanja drugih ljudi, bolje procene i bolje svesnosti različitih situacija. Opsednutost kompjuterom i informacionim tehnologijama ometa pravilan razvoj datih funkcija što može dovesti do pogoršanja socijalnih veština i sposobnost pravilnog zaključivanja.

\section{PREDMET ISTRAŽIVANJA}

Internet predstavlja jedno od najsavremenijih i najrasprostranjenijih sredstava informisanja i komunikacije. Virtuelni svet, izmenjen vid komunikacije, brži i lakši put informisanja dovode do mnogih promena u ljudskoj svesti i menjaju način razmišljanja i života. Željene informacije i nova poznanstva danas je moguće ostvariti samo jednim „klikom“, bez izlazaka iz kuće i svih ostalih priprema što predstavlja lakši i jeftiniji način života. Istraživanja na našim prostorima ukazuju na mnoge nedostatke, a naročito u obrazovanju.

Postavlja se pitanje negativnih strana interneta i da li „virtuelni život" može negativno da utiče na klasične međuljudske odnose, proces sazrevanja i odrastanja kod mladih. Potrebno je odrediti strategije i metode kojima bi prednosti informacione tehnologije bilo moguće usmeriti ka korisnijem korišćenju interneta i kompjutera u obrazovne svrhe. Nekontrolisana dostupnost računara i interneta kod mladih predstavlja izazov i daje mogućnost slobodnog izbora upotrebe. Da bi se povoljnosti interneta i računara koristili, kako za zabavu tako i za potrebe škole potrebno je na poseban način edukovati mlade i uticati na kvalitetniju raspodelu slobodnog vremena. Potrebno je ispitati u kojoj meri je korišćenje savremenih tehnologija sa akademskim dostignućem učenika i da li postoje razlike između učenika različitog nivoa postignuća i načina na koji koriste računar in Internet.

Cilj ovog istraživanja je da se utvrdi da li postoje razlike između učenika različitog školskog postignuća u odnosu na stepen korišćenja kompjutera i Interneta za potrebe škole, za druženje i zabavu i u odnosu na njihov stav prema ovim tehnologijama. Razlike između učenika u pogledu svrhe korišćenja kompjutera i Interneta i njihovog stava prema njihovom koriščenju daće nam indirektno uvid u to na koji način učenici sa boljim školskim postignućem koriste kompjuter i Internet, a na koji način ih koriste učenici sa lošijim školskim postignućem ukoliko razlike među njima postoje. Rezultati istraživanja pružiće nam uvid u maladaptivne načine korišćenja kompjutera i Interneta, kao i važne smernice na koji način organizovati vreme učenika kako bi savremene tehnologije koristili na produktivan način. Takođe, rezultati ovog istraživanja će nam pružiti važne informacije o stavu učenika prema korišćenju kompjutera i Interneta pomoću kojih možemo odrediti strategije kojima ćemo uticati na razvijanje svesti učenika o pozitivnim i negativnim stranama savremenih tehnologija. 


\section{HIPOTEZE}

Interesovanja učenika za informacione tehnologije su raznolika i razmatra se spremnost učenika srednjih škola da svoje znanje iz informatike primene na druge nastavne predmete i unaprede svoja akademska postignuća. Glavna hipoteza je da postoje razlike u pogledu svrhe korišćenja interneta i stava učenika prema internetu u odnosu na uspeh učenika i informatičku pismenost. Posebne hipoteze su: postoje razlike između učenika u stepenu korišćenja interneta i računara u svrhu obrazovanja u odnosu na uspeh, postoje razlike između učenika u pogledu stepena korišćenja kompjutera i Interneta za druženje i zabavu u odnosu na uspeh, postoje razlike između učenika u pogledu stava prema internetu u odnosu na uspeh učenika.

\section{METODE I TEHNIKE ISTRAŽIVANJA}

S obzirom na predmet istraživanja korišćena je deskriptivna metoda, servej metoda kojom u praksi ništa ne menjamo već samo posmatramo. Analizom varijanse vršeno je poređenje aritmetičkih sredina između različitih grupa ispitanika. Instrument kojim je vršeno istraživanje, konstruisan za dato istraživanje, je skala Likertovog tipa na četiri nivoa, preko koje su ispitanici iznosili svoje stavove, odnosno stepen slaganja ili neslaganja sa predloženom tvrdnjom. Nezavisnu varijablu predstavlja uspeh, dok su zavisne varijable koriščenje kompjutera i Interneta za potrebe škole, korišćenje kompjutera i Interneta za druženje i zabavu i stav učenika prema korišćenju kompjutera i Interneta. Pouzdanost prvog subtesta koji se odnosi na korišćenje interneta za potrebe škole iznosi $\alpha=$ 0,569 , pouzdanost drugog subtesta koji se odnosi na korišćenje kompjutera i interneta za druženje i zabavu iznosi $\alpha=0,617$ i pouzdanost trećeg subtesta koji se odnosi na stav učenika prema internetu je $\alpha=0,680$.

\section{REZULTATI ISTRAŽIVANJA I ANALIZA}

Uzorkom je obuhvaćeno 598 učenika, stanara Doma učenika srednjih škola Beograd. Uzorak je reprezentativan i s obzirom na veličinu uzorka moguće su izvesne generalizacije u okviru populacije koja je ispitivana.

$\mathrm{Na}$ osnovu podataka iz tabele 1 može se uočiti da postoje statistički značajne razlike u količini korišćenja Interneta za školu i druženje između učenika sa različitim uspehom. Kako bismo utvrdili između kojih grupa je pronađena razlika korišćen je Post hoc test koji ima za cilj da utvrdi između kojih grupa učenika postoje razlike $\mathrm{u}$ izraženosti postavljenih zavisnih varijabli.

$\mathrm{Na}$ osnovu podataka iz tabele 2 možemo zaključiti da odlični učenici više koriste internet za potrebe škole u odnosu na vrlo dobre. Odlični učenici takođe manje koriste internet za druženje u odnosu na sve ostale. Odlični imaju pozitivniji stav prema korišćenju Interneta u odnosu na dobre. Na osnovu dobijenih rezultata može se konstatovati da su naše hipoteze da postoje razlike između uče-
Table 1 Razlike između učenika u izraženosti ispitivanih konstruktora u odnosu na uspeh (ANOVA)

\begin{tabular}{|c|c|c|c|c|c|c|c|}
\hline Zavisne varijable & Uspeh & $\mathrm{N}$ & $\mathrm{M}$ & $\mathrm{SD}$ & $\mathrm{df}$ & $\mathrm{F}$ & $\mathrm{p}$ \\
\hline Škola & Dovoljan & 273 & 8,71 & 1,94 & 3 & 1,55 & $0,020 *$ \\
\hline & Dobar & 269 & 8,35 & 2,00 & & & \\
\hline & Vrlo dobar & 52 & 8,63 & 2,22 & & & \\
\hline & Odličan & 4 & 8,50 & 2,38 & & & \\
\hline & Ukupno & 598 & 8,54 & 1,99 & & & \\
\hline & Dovoljan & 273 & 6,05 & 2,31 & 3 & 10,63 & $0,000 *$ \\
\hline & Dobar & 269 & 6,62 & 2,51 & & & \\
\hline & Vrlo dobar & 52 & 7,88 & 3,25 & & & \\
\hline & Odličan & 4 & 9,75 & 3,20 & & & \\
\hline & Ukupno & 598 & 6,49 & 2,56 & & & \\
\hline & Dovoljan & 273 & 6,75 & 1,64 & 3 & 1,79 & 0,148 \\
\hline & Dobar & 269 & 6,54 & 1,84 & & & \\
\hline & Vrlo dobar & 52 & 6,19 & 1,85 & & & \\
\hline & Odličan & 4 & 7,00 & 1,41 & & & \\
\hline & Ukupno & 598 & 6,61 & 1,75 & & & \\
\hline
\end{tabular}

Table 2 Razlika između učenika u izraženosti ispitivanih konstruktora u odnosu na uspeh (Post hoc)

\begin{tabular}{|c|c|c|c|c|}
\hline $\begin{array}{c}\text { Zavisna } \\
\text { varijabla }\end{array}$ & Uspeh (I) & Uspeh $(J)$ & $\begin{array}{c}\text { Razlika } \\
\text { M (I-J) }\end{array}$ & $p$ \\
\hline \multirow{12}{*}{ Škola } & \multirow{3}{*}{ odličan } & vrlodobar & $0,36^{*}$ & 0,03 \\
\hline & & dobar & 0,08 & 0,79 \\
\hline & & dovoljan & 0,21 & 0,83 \\
\hline & \multirow{3}{*}{ vrlodobar } & odličan & $-0,36 *$ & 0,03 \\
\hline & & dobar & $-0,29$ & 0,35 \\
\hline & & dovoljan & $-0,15$ & 0,88 \\
\hline & \multirow{3}{*}{ dobar } & odličan & $-0,08$ & 0,08 \\
\hline & & vrlodobar & 0,29 & 0,34 \\
\hline & & dovoljan & 0,13 & 0,90 \\
\hline & \multirow{3}{*}{ dovoljan } & odličan & $-0,21$ & 0,83 \\
\hline & & vrlodobar & 0,15 & 0,88 \\
\hline & & dobar & $-0,13$ & 0,90 \\
\hline \multirow{12}{*}{ Druženje } & \multirow{3}{*}{ odličan } & vrlodobar & $-0,56^{*}$ & 0,00 \\
\hline & & dobar & $-1,83^{*}$ & 0,00 \\
\hline & & dovoljan & $-3,70^{*}$ & 0,00 \\
\hline & \multirow{3}{*}{ vrlodobar } & odličan & $0,56^{*}$ & 0,00 \\
\hline & & dobar & $-1,27^{*}$ & 0,00 \\
\hline & & dovoljan & $-3,13^{*}$ & 0,01 \\
\hline & \multirow{3}{*}{ dobar } & odličan & $1,83^{*}$ & 0,00 \\
\hline & & vrlodobar & $1,27^{*}$ & 0,00 \\
\hline & & dovoljan & $-1,87$ & 0,15 \\
\hline & \multirow{3}{*}{ dovoljan } & odličan & $3,70^{*}$ & 0,00 \\
\hline & & vrlodobar & $3,13^{*}$ & 0,01 \\
\hline & & dobar & 1,87 & 0,15 \\
\hline \multirow{12}{*}{ Stav } & \multirow{3}{*}{ odličan } & vrlodobar & 0,21 & 0,17 \\
\hline & & dobar & $0,56^{*}$ & 0,03 \\
\hline & & dovoljan & $-0,25$ & 0,78 \\
\hline & \multirow{3}{*}{ vrlodobar } & odličan & $-0,21$ & 0,17 \\
\hline & & dobar & 0,35 & 0,18 \\
\hline & & dovoljan & $-0,45$ & 0,61 \\
\hline & \multirow{3}{*}{ dobar } & odličan & $-0,56^{*}$ & 0,03 \\
\hline & & vrlodobar & $-0,35$ & 0,18 \\
\hline & & dovoljan & $-0,81$ & 0,37 \\
\hline & \multirow{3}{*}{ dovoljan } & odličan & 0,25 & 0,78 \\
\hline & & vrlodobar & 0,45 & 0,61 \\
\hline & & dobar & 0,81 & 0,37 \\
\hline
\end{tabular}

${ }^{\star}$ Razlike su značajne na nivou o,o5 
nika u pogledu korišćenja interneta i računara u odnosu na uspeh, da postoje razlike između učenika u pogledu druženja i zabave učenika u odnosu na uspeh i postoje razlike između učenika u pogledu stava prema internetu u odnosu na uspeh.

\section{ZAKLJUČAK}

Predstavljenim istraživanjem pokušaj je bio da se proceni povezanost različitog uspeha učenika u školi i načina korišćenja interneta i kompjutera, koliko je korišćenje interneta zastupljeno za potrebe škole, koliko za druženje i zabavu i kakav stav učenici različitog akademskog postignuća imaju prema internetu i prema informacionoj tehnologiji.

Rezultati istraživanja ukazuje da postoje značajne razlike u količini korišćenja interneta za školu i druženje između učenika sa različitim uspehom. Zaključak do koga se došlo je da učenici sa boljim uspehom koriste internet na kvalitetniji način, što i rezultira boljim uspehom. Manje vremena provode za računarom, vreme koje koriste je namensko i imaju pozitivniji stav prema internetu. Učenici sa slabijim uspehom više vremena provode za računarom, način na koji ga koriste je uglavnom zabava i imaju negativniji stav prema internetu.

Može se reći da su svesni svojih nedostataka pri korišćenju, što ukazuje na potrebu uključivanja stručnjaka i ostalih eksperata koji se bave pedagogijom slobodnog vremena i eksperata u organizaciji nastave i nastavnog plana i programa, kao i važne smernice na koji način organizovati vreme učenika kako bi savremene tehnologije koristili na produktivan način. Rezultati ovog istraživanja nam pružaju važne informacije o stavu učenika prema korišćenju interneta pomoću kojih možemo odrediti strategije kojima ćemo uticati na razvijanje svesti učenika o pozitivnim i negativnim stranama savremenih tehnologija.
Internet sam po sebi ne može da garantuje dobru nastavu ili učenje, ali se mogu eksploatisati njegovi potencijali kako bi se obezbedila efikasna nastava, učenje i istraživanje. Mnogi teoretičari koji se bave problemom obrazovanja mladih za korišćenje informacione tehnologije, naglašavaju važnost uvođenja novih obrazovnih programa. Pored navedenog, neophodno je uskladiti veštine i premostiti jaz između mlađih generacija i prosvetnog kadra.

Danas je tehnologija u rukama mladih, dok je obrazovanje u rukama odraslih. Mladima je potrebno da nauče kako da unaprede socijalne veštine, dok kod nastavnog kadra je potrebno unaprediti tehnološke veštine, što je i predviđeno smernicama Nacionalnog prosvetnog saveta.

\section{LITERATURA}

[1] A. Brigs, P. Berk, „Društvena istorija medija“, Beograd, Clio, 2006.

[2] R. Šnel „Leksikon savremene culture“, Beograd, Izdavačka kuća PLATO, 2008.

[3] Frenk Dž. Lenčer, Dž. Boli, „Kultura sveta“, Beograd, Clio, 2006.

[4] M. Carnoy, ICT in Education: Possibilities and Challenges. U: Inaugural Lecture of the UOC 2004-2005 Academic Year (2004: Barcelona) [online]

[5] Nacionalni prosvetni savet Republike Srbije, „Smernice za unapređivanje uloge informaciono komunikacionih tehnologija u obrazovanju“, 2013.

[6] S. Geri, i V. Gigi, „Internet mozak“, Novi Sad: Psihopolis institute d.o.o., 2011.

[7] N. Trnavac, i J. Đorđević, „Pedagogija” Beograd, Naučna knjiga Nova, 2002.

\section{ABILITY OF HIGH SCHOOL STUDENTS TO USE THE INTERNET FOR EDUCATIONAL PURPOSES}

\footnotetext{
Abstract:

The development of information technology lead to the possibility of introducing more contemporary and more productive methods of activities and development in all spheres of social life, but also in education. The aim of this research was to examine what are students' interests in the field of information technology and are the high school students willing to apply their knowledge of computer science to other school subjects and improve their academic achievements. The research results showed that students use the contents from the Internet mostly for entertainment purposes, and also use them for learning and school need, but they do not affect academic achievements in other subjects. This points to the need for more organized use of information technologies and more optimal use for educational purposes.
}

\section{Key words:}

internet, education, academic achievement, information technology, knowledge. 